\title{
Potential overestimation of bacterial respiration rates in oligotrophic plankton communities
}

\author{
María Aranguren-Gassis*, Eva Teira, Pablo Serret, Sandra Martínez-García, \\ Emilio Fernández
}

Universidad de Vigo, Departamento de Ecología y Biología Animal, Carretera Colegio Universitario s/n, 36310 Vigo, Pontevedra, Spain

\begin{abstract}
Adequate bacterial respiration (BR) estimations are necessary to understand the flow of carbon through marine plankton food webs. A considerably higher bacterial contribution to total microbial plankton community respiration (CR) has been observed in oligotrophic systems compared to more productive systems. Classical BR estimation procedures, typically oxygen consumption measurements, comprise pre-incubation filtration to separate bacteria from the rest of the plankton community and long incubation times $(24 \mathrm{~h})$. The resulting disruption of the community linkages over long time periods might affect BR measurements, especially in oligotrophic systems characterized by tightly coupled microbial food webs. In this study, BR data were compiled from 2 contrasting environments: the highly productive Ría de Vigo (NW Spain) and the North Atlantic oligotrophic gyre. Standard procedures or in vivo electron transport system (ETS) activity (non prefiltered and short-time incubation) procedures were used to obtain a total of 209 BR estimations. Bacterial contribution to plankton CR was significantly higher in oligotrophic than in highly productive conditions $(155 \%$ and $42 \%$, respectively) when using standard procedures, while similar values were observed $(31 \%$ and $30 \%)$ with in vivo ETS procedures. The relation between plankton $\mathrm{CR}$ and $\mathrm{BR}$ along the studied productivity gradient suggests that bacterial contribution to total CR varies less than previously assumed with an average value approximating $30 \%$ through different trophic situations.
\end{abstract}

KEY WORDS: Bacterial respiration · Pre-filtration · Oligotrophic plankton communities

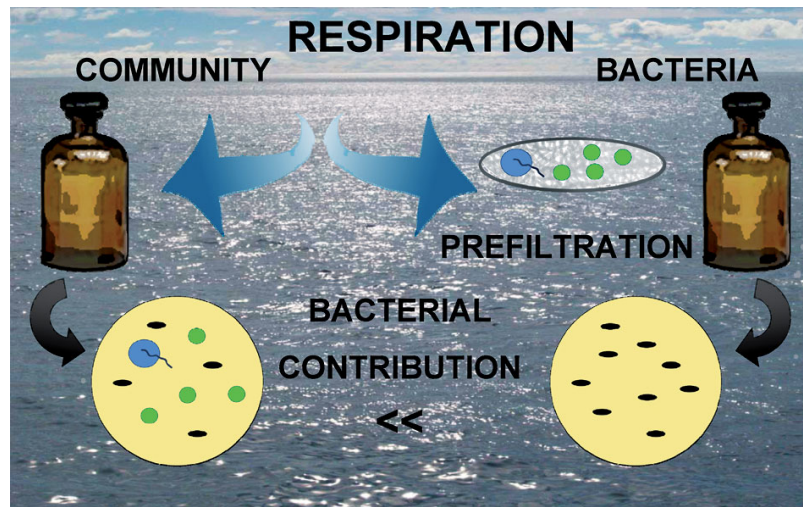

Pre-filtration of water samples for elimination of zooplankton and phytoplankton causes overestimation of the bacterial contribution to community respiration in oligotrophic pelagic systems.

Image: M. Aranguren-Gassis

\section{INTRODUCTION}

Bacterioplankton respiration is uniquely related to the amount of organic carbon returned to the inorganic pool by bacteria and is thus critical to understanding the carbon cycling of aquatic ecosystems (Jahnke \& Craven 1995). Concurrent measurements of bacterial respiration and bacterial production are necessary to estimate the bacterial carbon demand and bacterial growth efficiency (del Giorgio \& Cole 1998, Gasol et al. 2008). However, estimates of carbon flow through bacteria are still not well constrained mainly due to methodological difficulties (Gasol et al. 2008).

Classic bacterial respiration measurements, typically dissolved oxygen consumption rates, require 
the separation of bacteria from the rest of the plankton community. Separation is usually done by preincubation filtration through $\sim 0.8 \mu \mathrm{m}$ (between 0.6 and $3 \mu \mathrm{m}$ ) filters, and respiration estimated in the filtered fraction is assumed to be the bacterial respiration (Robinson 2008). Using pre-filtration standard methodologies, a major contribution (82 to $98 \%$ ) of the bacterial respiration to total microbial plankton community respiration has been observed in oligotrophic, in contrast to more productive, systems (9 to $30 \%$; Biddanda et al. 2001). Pre-filtration procedures may have obvious disadvantages derived from the disruption of the plankton community linkages (Gasol \& Morán 1999, Robinson 2008) as well as changes of the organic carbon availability (Gasol \& Morán 1999). Such methodological problems might lead to erroneous estimates of bacterial respiration in pre-filtered samples (Teira et al. 2010), especially in oligotrophic waters, where a tight coupling between bacterial and protistan grazers exists and the dissolved organic carbon stock is reduced.

Recently, the electron transport system (ETS) activity measurement technique has been modified to obtain in vivo respiration measurements of natural marine microplankton samples (Martínez-García et al. 2009). It provides a unique tool to estimate bacterial respiration while avoiding pre-filtration procedures and long incubation periods (Teira et al. 2010).

In the present study, we compared estimates of bacterial respiration in productive and oligotrophic waters, using both the standard (pre-filtration and long incubation) procedure and the in vivo ETS (non pre-filtration and short incubation) method in order to explore whether standard procedures affect the contribution of bacteria to microbial plankton community respiration.

\section{MATERIALS AND METHODS}

\section{Study area}

Bacterial respiration was measured in 2 contrasting systems: the North Atlantic Oligotrophic gyre and the highly productive Ría de Vigo (NW Spain). Bacterial respiration was measured at 31 stations located in the North Atlantic Oligotrophic gyre during the CARPOS-cruise in October to November 2006 on board RV 'Hespérides'. Seven stations were occupied along a transect crossing the north-east boundary of the region from $13^{\circ} \mathrm{W}, 34^{\circ} \mathrm{N}$ to $34^{\circ} \mathrm{W}, 26^{\circ} \mathrm{N}$ and the rest of stations corresponded to two $8 \mathrm{~d}$ Lagrangian experiments located at $36.6^{\circ} \mathrm{W}, 25^{\circ} \mathrm{N}$ and at $26.3^{\circ} \mathrm{W}$,

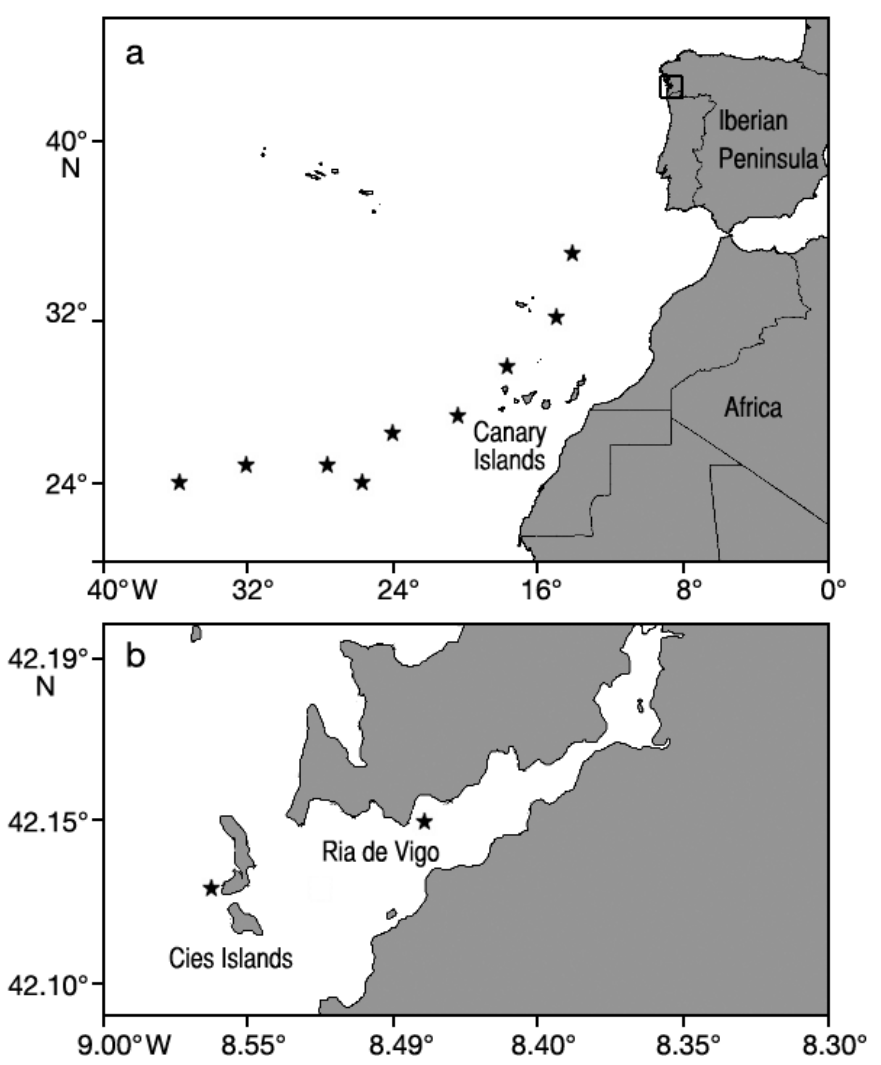

Fig. 1. Location of the stations sampled in this study. (a) Location of the stations sampled during the CARPOS cruise in the Atlantic Ocean ( $\star$ ). The square signals the location of the enlarged map of (b) the Ría de Vigo, where $\star=$ stations at which samples for the microcosm and mesocosm experiments were collected

$24.8^{\circ} \mathrm{N}$ (Fig. 1a). Bacterial respiration was measured at 7 stations (along the transect) using standard procedures and at 28 stations (during the transect and the Lagrangian experiments) using the in vivo ETS method. Water samples were drawn from 3 to 5 discrete depths between 0 and $150 \mathrm{~m}$ with 201 Niskin metal-free bottles mounted in a CTD rosette (for details, see Teira et al. 2010, Aranguren-Gassis et al. 2011).

Bacterial respiration was also measured in the Ría de Vigo embayment during 4 mesocosm experiments conducted during 4 contrasting periods in 2005 (spring, summer and autumn) and 2006 (winter) using standard procedures. Water was collected from a central station of the embayment $\left(42^{\circ} 14.9^{\prime} \mathrm{N}\right.$, $8^{\circ}$ 47.18' W; Fig. 1b) and 35001 polyethylene bags were filled by inverse filtration through a $200 \mu \mathrm{m}$ pore size mesh. Oil spill simulations were carried out in some of the bags during the experiments. Both control and fuel-added treatment data were included in the present work since no differences were found 
for community or bacterial respiration (Wilcoxon signed-rank test between control and fuel-added estimations: $Z=-1.153, \mathrm{p}=0.249$ for community respiration and $Z=-0.454, \mathrm{p}=0.650$ for bacterial respiration). The plankton community remained enclosed for $8 \mathrm{~d}$, with irradiance and temperature conditions similar to those in their natural environment. Subsamples (24 l) were taken every day for chemical and biological analyses and incubations (see Teira et al. 2007 for details). Moreover, bacterial respiration was measured using the in vivo ETS method during 6 microcosm experiments conducted in winter, spring and summer 2008. Surface seawater was collected in the central station of the Ría de Vigo embayment (the same as for the mesocosm experiments) and at a station located on the shelf adjacent to the Ría de Vigo (Fig. 1b). Seawater was filtered through $200 \mu \mathrm{m}$ pore size mesh and immediately transferred to 121 polycarbonate bottles. The plankton community was monitored for $3 \mathrm{~d}$ for each experiment, with cool white light and temperature similar to that in situ (see Martínez-García et al. 2010 for details). Only data from the control treatment of the microcosm experiments have been included in the present work.

\section{Chlorophyll a concentration}

Water samples of $250 \mathrm{ml}$ (mesocosms and CARPOS) or $150 \mathrm{ml}$ (microcosms) were collected. Water samples were filtered sequentially through different pore size filters: 20 and $0.2 \mu \mathrm{m}$ during mesocosm experiments; 2 and $0.2 \mu \mathrm{m}$ during CARPOS sampling; and 20,5,2 and $0.2 \mu \mathrm{m}$ during microcosm experiments. In all cases, pigments were extracted with $90 \%$ acetone at $4{ }^{\circ} \mathrm{C}$ over at least $12 \mathrm{~h}$ in the dark. The chlorophyll a (chl a) concentration was determined with a Turner Designs 700 fluorometer calibrated with pure chl a standard (Welschmeyer 1994).

\section{Primary production}

Primary production rates were estimated with the ${ }^{14} \mathrm{C}$ radiocarbon method during mesocosm and microcosm experiments in the Ría de Vigo and from the in vitro changes in dissolved oxygen during the CARPOS project in the North Atlantic gyre.

For the transect sampled at the CARPOS project, on-deck incubations for gross primary production estimations were conducted with seawater collected from 5 depths within the euphotic zone. Irradiances between 0.3 and $87 \%$ of surface values were adjusted with neutral density meshes, and the in situ temperature range was simulated with running surface seawater plus 2 coolers. During the Lagrangian experiments, incubations were conducted in situ. All incubations started pre-dawn. The incubation and analytical (automated Winkler with potentiometric end point) procedures were described in detail by Aranguren-Gassis et al. (2011) and were similar to those described later for the total respiration measurements. Gross primary production rates obtained from in vitro changes in the dissolved oxygen were converted to carbon units using a photosynthetic quotient $(\mathrm{PQ})=1.4$ (Laws 1991). Similar results were obtained using a range of $\mathrm{PQ}$ values between 1 and 1.8.

During mesocosm and microcosm experiments, 75 to $100 \mathrm{ml}$ bottles (3 light and 1 dark) were filled with seawater and $185 \mathrm{kBq}(5 \mu \mathrm{Ci})$ of $\mathrm{NaH}^{14} \mathrm{CO}_{3}$ was added. Samples were incubated over 24 or 3 to $4 \mathrm{~h}$ in similar conditions to the meso- and microcosms, respectively. Samples were then filtered through glass fibre filters (Whatman GF/F) during mesocosm experiments and sequentially filtered through 20,5, 2 and $0.2 \mu \mathrm{m}$ polycarbonate filters during microcosm experiments. The filters were exposed to concentrated $\mathrm{HCl}$ fumes for $24 \mathrm{~h}$ to eliminate unincorporated ${ }^{14} \mathrm{C}$. The radioactivity of the samples was measured with a liquid scintillation counter using the external standard and the channel ratio methods for quenching correction.

\section{Phytoplankton and bacterial biomass}

Prokaryote abundance was measured by flow cytometry as described by Gasol \& del Giorgio (2000). Samples were stained with SYBR Green, and bacteria were detected by their signature of side scatter (SSC) and green fluorescence with a BectonDickinson FACSCalibur cytometer. The empirical calibration between SSC and mean cell diameter using the sequential filtration method described by Zubkov et al. (1998) were used to estimate the biovolume (BV) of bacterioplankton cells. BV was finally converted into biomass by using the volume-to-C conversion factor from Norland (1993: $\mathrm{fg} \mathrm{C}_{\mathrm{C}} \mathrm{cell}^{-1}=$ $120 \times$ BV 0.72) during the microcosm experiments and from Fukuda et al. (1998) during mesocosm experiments $\left(20 \mathrm{fg} \mathrm{C} \mathrm{Cell}^{-1}\right)$, and using an allometric relationship from Gundersen et al. (2002: $\mathrm{fg} \mathrm{C} \mathrm{Cell}^{-1}=$ $108.8 \times$ BV 0.898) during the CARPOS cruise.

During microcosm experiments, phytoplankton biomass was estimated from phytoplankton cell abun- 
dance (see Martínez-García et al. 2010 for details). Picophytoplankton cells were counted by flow cytometry with a Becton-Dickinson FACSCalibur cytometer. Picoplankton groups were identified on the basis of their relative red and orange fluorescence and SSC signals. The empirical calibration between SSC and mean cell diameter described by CalvoDíaz \& Morán (2006) was used to estimate BV, which was further converted into carbon units using conversion factors from Worden et al. (2004). Nano- and microphytoplankton were preserved with Lugol's solution and counted under the microscope. Cell BV was then estimated from direct measurements and by approximating cell shape to the closet geometric shape following Olenina et al. (2006). Conversion of cell BV to carbon units was performed following Menden-Deuer \& Lessard (2000).

Chl a concentration was used as an approximation of the phytoplankton biomass during mesocosm experiments and the CARPOS project since cell abundance data were not available. Chl a conversion to carbon units was made following Marañón et al. (2007) and Cermeño et al. (2005) for CARPOS stations and mesocosm experiments, respectively. The carbon-to-chl a ratios (mg C $\mathrm{mg}^{-1} \mathrm{chl}$ a) used for CARPOS stations were 103 and 21 for $<2 \mu \mathrm{m}$ phytoplankton and 247 and 60 for $>2 \mu \mathrm{m}$ phytoplankton in the upper mixed layer and in the deep chlorophyll maximum, respectively. The carbon-to-chl a ratios (mg C mg-1 chl a) used for mesocosm experiments were: $29.8(<2 \mu \mathrm{m})$ and $39.3(>2 \mu \mathrm{m})$ in July and September (stratification conditions); $34.8(<2 \mu \mathrm{m})$ and $60.5(>2 \mu \mathrm{m})$ in January (winter mixing); and 93.3 $(<2 \mu \mathrm{m})$ and $47.5(>2 \mu \mathrm{m})$ in March (upwelling).

\section{Respiration rates}

Three different methods were used to estimate both bacterial and total respiration rates.

\section{Standard procedures}

The in vitro dissolved oxygen consumption (Winkler) method was used. For total community respiration rates, water samples were taken in $100 \mathrm{ml}$ nominal volume dark borosilicate bottles individually calibrated, overflowing $>200 \mathrm{ml}$. For each datum, 4 bottles were fixed immediately for initial oxygen concentration measurements and 4 additional ones were fixed after $24 \mathrm{~h}$ incubation, all of them following the recommendations of Grasshoff et al. (1999). In situ incubations were conducted during mesocosm and CARPOS Lagrangian experiments, while on-deck incubations were conducted during the latitudinal transect of the CARPOS project. In the latter, temperature was kept similar to that in situ by using circulating surface seawater and 2 coolers. Dissolved oxygen was measured by precision Winkler titration performed with a Metrohm 716 DMS Titrino using potentiometric end point determination (Oudot et al. 1988, Serret et al. 1999). Community respiration (CR) was calculated from the difference between the averaged dissolved oxygen concentration in the incubated dark bottles and that in the initial samples.

For bacterial respiration (BR), water was filtered before the incubation through a capsule (Millipore Opticap XL10) with Polysep II (borosilicate glass microfibre and cellulose-ester membrane) 1.0/1.2 $\mu \mathrm{m}$ pore size filter. During our experiments, the use of filter capsules enabled us to increase the filtration surface, thereby avoiding silting problems and precluding the use of vacuum pressure. In this way, the cell breaking effect during our pre-filtrated process should be negligible. Pre-filtered samples were incubated at the same time and under the same conditions as the non pre-filtered samples, and dissolved oxygen was measured with identical procedures. BR was calculated from the difference between the averaged dissolved oxygen concentration in pre-filtered and incubated dark bottles and that in the prefiltered initial samples.

\section{In vivo ETS method (Martínez-García et al. 2009)}

Four 100 to $300 \mathrm{ml}$ dark bottles were filled with seawater. One bottle was immediately fixed by adding formaldehyde ( $2 \% \mathrm{w} / \mathrm{v}$ final concentration) and used as a killed control. Samples were inoculated with a sterile solution of 2-para (iodo-phenyl)-3(nitrophenyl)-5(phenyl)-tetrazolium chloride (INT) and incubated at near in situ temperature for $1 \mathrm{~h}$ in microcosm experiments and for 3 to $5.5 \mathrm{~h}$ in CARPOS. After incubation, samples were fixed by adding formaldehyde and sequentially filtered through 0.8 and $0.2 \mu \mathrm{m}$ pore size polycarbonate filters. The INTformazan (INT-F) was extracted from the cells with propanol following the procedures described by Martínez-García et al. (2009), and the absorbance at $485 \mathrm{~nm}$ of the resulting solution was measured using a spectrophotometer (Beckman model DU640). The INT-F concentration was calculated by applying a standard curve previously elaborated with pure INTF dissolved in propanol. Respiration rates were esti- 
mated from the INT-F concentration and transformed to oxygen consumption using the conversion factor obtained by Martínez-García et al. (2009) with nonaxenic algal cultures (12.8). CR was estimated as the sum of the activity in the 0.2 and $0.8 \mu \mathrm{m}$ filters, and BR was estimated as the activity measured in the $0.2 \mu \mathrm{m}$ filter.

The 2 data sets used in this study corresponding to respiration rates based on $\mathrm{O}_{2}$ consumption measurements and on in vivo ETS are available at the global respiration data base: www.uea.ac.uk/env/people/ facstaff/plankton (data compiled and maintained by C. Robinson initially for Robinson 2008).

In vitro ETS method (Packard 1971)

Potential respiration was measured simultaneously to Winkler respiration measurements, at 6 oligotrophic stations during the CARPOS project. At each station, 1 to 51 of sea water were sequentially filtered through 0.8 and $0.2 \mu \mathrm{m}$ polycarbonate filters. Filters were then frozen with liquid nitrogen and stored for subsequent analysis in the laboratory. Samples were processed following the recommendations of Packard (1971). Briefly, ETS enzymes were extracted by homogenisation in a phosphate buffer solution, at 0 to $4^{\circ} \mathrm{C}$ for $10 \mathrm{~min}$, with a Teflon-glass tissue grinder. The crude enzyme preparation was centrifuged at 0 to $4^{\circ} \mathrm{C}$ at $224 \times g$. Then substrate (NADH and NADPH) and INT salt were added to the clarified enzymatic solution and the mix was incubated 20 min in the dark at $25^{\circ} \mathrm{C}$. The resulting INT-F absorbance at $490 \mathrm{~nm}$ was measured using a spectrophotometer (Beckman model DU640). ETS activity was calculated with the equation given by Packard \& Williams (1981):

$$
\begin{aligned}
& \text { ETS activity }\left(\mu \mathrm{O}_{2} \mathrm{l}^{-1} \mathrm{~h}^{-1}\right)= \\
& \qquad 60 \times H \times S \times A b s /(1.42 \times V \times f \times t)
\end{aligned}
$$

where $H$ is the homogenate volume (in $\mathrm{ml}$ ), $S$ is the volume of the enzyme preparation, $A b s$ is the absorbance of the sample corrected for blank absorbance and turbidity $(760 \mathrm{~nm}), V$ is the volume of filtered seawater (in 1), $f$ is the volume of incubated mix (in $\mathrm{ml}$ ), $t$ is the incubation time (in $\mathrm{min}$ ), 60 converts minutes to hours, and 1.42 converts the INT-F formed to oxygen units (in $\mu \mathrm{l}$ ).

\section{Statistical procedures}

Normal distribution of the data was always checked before statistical analysis through Kolmogorov-
Smirnov and Shapiro-Wilk tests with a 0.05 significance level. All statistical tests except type II regressions were made in SPSS 15.0 support. For type II regression calculations, RMA software designed by San Diego University was used www.bio.sdsu.edu/ pub/andy/rma.html.

\section{RESULTS AND DISCUSSION}

\section{Characterization of the plankton communities}

The data set obtained in this study was classified according to the corresponding chl a concentration of the samples. Chlorophyll concentration has usually been used as an index of the productivity of aquatic systems since it enables estimation of the phytoplankton biomass and correlates with nutrient availability (Falkowski et al. 1998). A chl a concentration of $0.5 \mathrm{mg} \mathrm{m}^{-3}$ was chosen to separate oligotrophic samples from mesotrophic samples because chl a concentration rarely exceeds that value in the oligotrophic gyres, even at the deep chlorophyll maximum (see review by Robinson et al. 2006). Data were consequently separated into 2 groups: (1) the first data group represents mesotrophic conditions and contains 54 units of data from samples with chl a concentration $>0.5 \mathrm{mg} \mathrm{m}^{-3}$ obtained during mesocosm and microcosm experiments in the Ría de Vigo (Fig. 1b); (2) the second data group represents oligotrophic conditions and includes data from samples with chl a concentration $<0.5 \mathrm{mg} \mathrm{m}^{-3}$. This group contains 139 data units from the North Atlantic oligotrophic gyre and 6 data units from mesocosm and microcosm experiments in the Ría de Vigo (Fig. 1a,b).

Significant differences were found in the mean contribution of the picophytoplankton to chl a concentration, the mean primary production rate and the mean bacteria:phytoplankton biomass ratio between both data groups (Fig. 2), which reflects the contrasting structure and productivity levels of the plankton community. Mean chl a concentration and primary production were, respectively, 1 and 2 orders of magnitude higher for the mesotrophic conditions than the oligotrophic conditions, whereas picophytoplankton contribution and the bacteria:phytoplankton biomass ratio were 2 to 4 times higher for the oligo- than for the mesotrophic conditions. The chosen chl a concentration criterion generates 2 data groups that appropriately represent the widely discussed contrasting ends of the planktonic productivity gradient in marine environments (Legendre \& Rassoulzadegan 1995, Cotner \& Biddanda 2002 and references therein). 

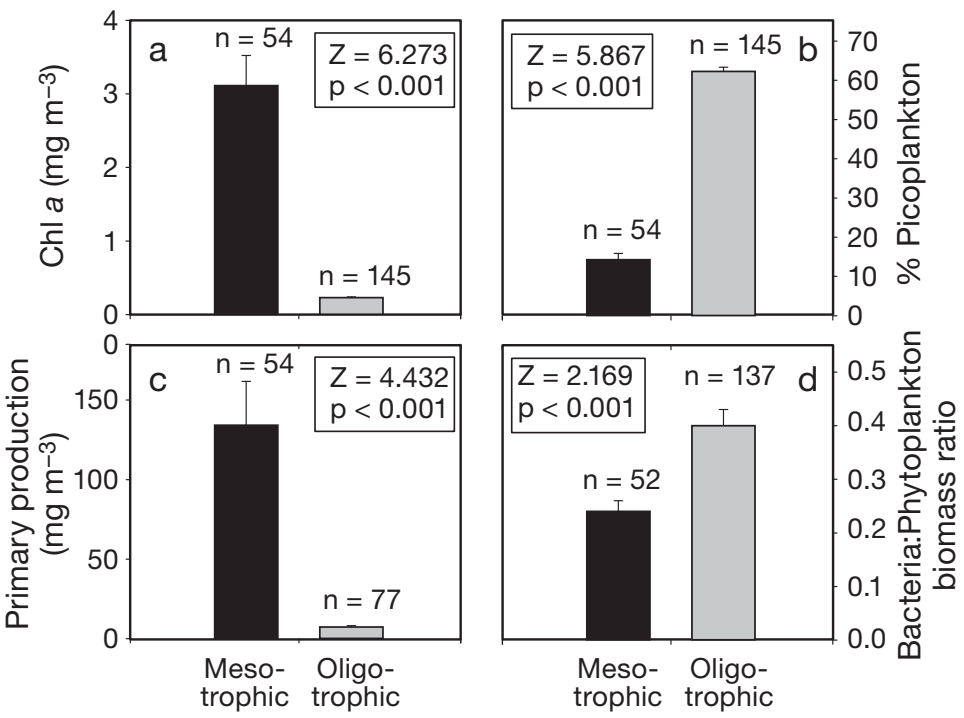

Fig. 2. Comparison between mesotrophic (black) and oligotrophic (grey) conditions for (a) average chlorophyll a (chl a) concentration, (b) picophytoplankton contribution to chl a concentration, (c) primary production and (d) the bacterial:phytoplankton biomass ratio. Error bars represent standard error, and $\mathrm{n}$ is the number of samples. $Z$ and $\mathrm{p}$ are the parameters from the non-parametric Kolmogorov-Smirnov test
Mean \%BR was significantly higher (Table 1) in oligotrophic than in mesotrophic conditions when using standard procedures, whereas a similar mean \%BR was estimated in both cases with the in vivo ETS method. Major practical differences between both methodologies comprise pre-filtration and $24 \mathrm{~h}$ incubations for the standard oxygen consumption, and non-prefiltration and $<5 \mathrm{~h}$ incubations for the in vivo ETS method. A constant relationship between total CR rates concurrently derived from both methods was found over a wide range of oceanic trophic conditions using the same experimental approaches (Martínez-García et al. 2009), which suggests that time incubation differences (24 h versus 1-5 h) would not differentially affect CR estimates along the productivity gradient. Therefore, despite BR measurements being simultaneously conducted with both methods only in 10 oligotrophic samples, our results strongly suggest that standard procedures involving pre-filtration might cause a major overestimation of BR under oligotrophic

\section{Potential effects of standard procedures on bacterial respiration estimations}

The contribution of $\mathrm{BR}$ to $\mathrm{CR}(\% \mathrm{BR})$ was estimated in samples from both data groups using standard $(24 \mathrm{~h}$ oxygen consumption of pre-filtered samples) or in vivo ETS activity procedures (non pre-filtered short incubations; Fig. 3). The frequency distribution of \%BR data approximates a normal distribution in all cases except when standard methodologies were used in oligotrophic conditions. In mesotrophic conditions, the most frequent values of \%BR ranged from 30 to $50 \%$ and from 20 to $30 \%$ with standard and in vivo ETS methodologies, respectively. In oligotrophic conditions, similar values (20 to $40 \%$ ) were found when the in vivo ETS procedure was used, in contrast to the difference in the bacteria:phytoplankton biomass ratio, whilst the most frequent $\% \mathrm{BR}$ value ranges were $80-90$, $130-140$ and $300-400 \%$ when the standard oxygen consumption methodology was used.
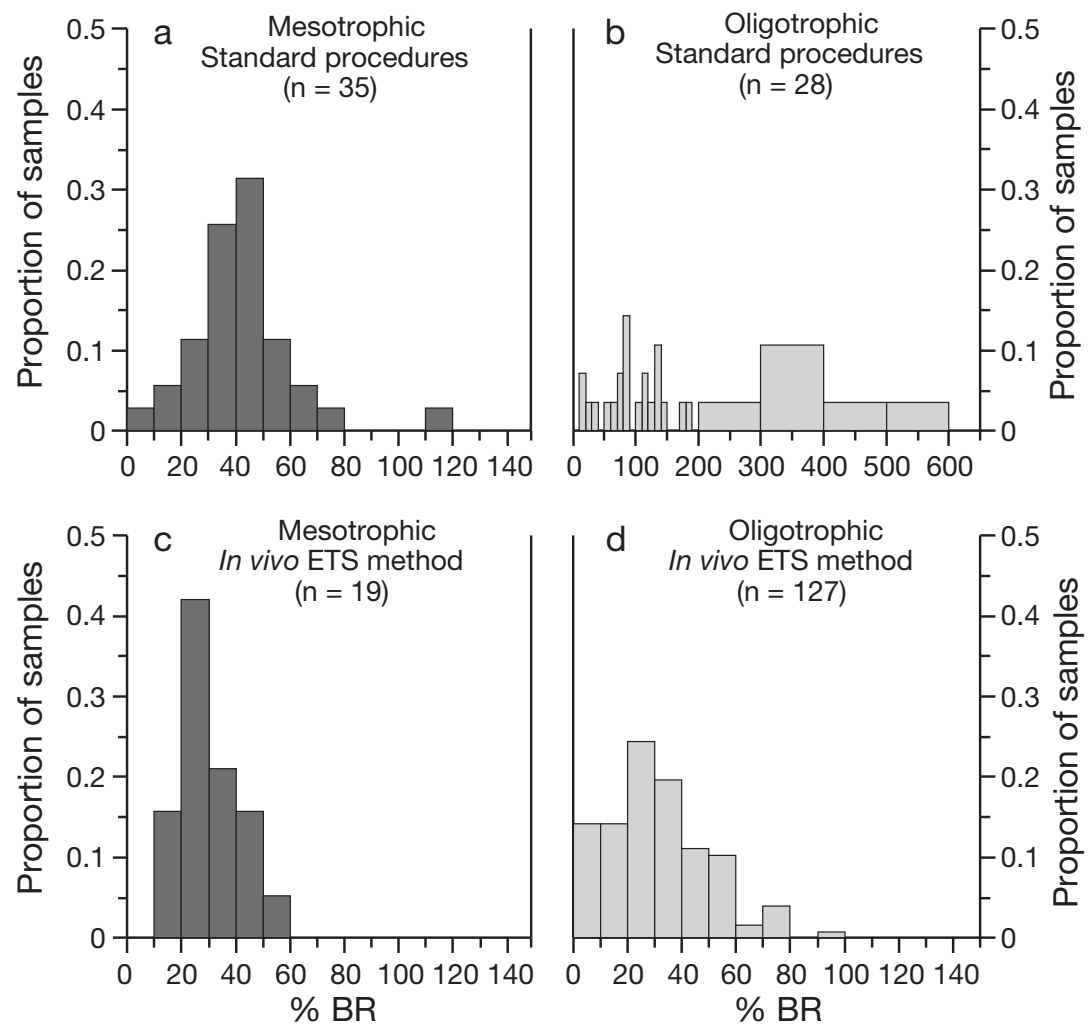

Fig. 3. Relative frequency of the bacterial respiration contribution to community respiration (\%BR) in mesotrophic (dark grey) and oligotrophic conditions (light grey) with $(\mathrm{a}, \mathrm{b})$ standard procedures and $(\mathrm{c}, \mathrm{d})$ the in vivo electron transport system (ETS) method 
Table 1. Means, number of data (n) and standard errors of the bacterial respiration contribution to total respiration (\%) for standard and in vivo electron transport system (ETS) methods. Results of the non-parametric KolmogorovSmirnov test between mesotrophic and oligotrophic conditions for each method are also shown

\begin{tabular}{|llrrrrc|}
\hline Method & System & Mean & SE & $\mathrm{n}$ & \multicolumn{2}{c|}{ Kolmogorov-Smirnov } \\
& conditions & \multicolumn{1}{c}{ (\%) } & & & \multicolumn{1}{c}{$\mathrm{p}$} \\
\hline Standard & Mesotrophic & 41.78 & 3.32 & 35 & 2.902 & $<0.001$ \\
& Oligotrophic & 154.45 & 25.24 & 28 & & \\
In vivo & Mesotrophic & 30.28 & 2.64 & 19 & 0.714 & 0.688 \\
ETS & Oligotrophic & 31.16 & 1.67 & 127 & & \\
\hline
\end{tabular}

conditions. From those 10 simultaneously-measured samples, only $2 \%$ BR estimations agree, and the others resulted in 3 to 11 times higher \%BR with standard procedures than with in vivo ETS measurements. It is also very likely that the potential effects of pre-filtration could be exacerbated by the long incubation time $(24 \mathrm{~h})$ necessary for pre-filtered oxygen consumption estimations.

It has been suggested that separation of bacteria from their predators might result in elevated bacterial growth as grazing pressure is greatly reduced (Weisse \& Scheffel-Möser 1991, Robinson 2008). Moreover, filtration can affect substrate availability due to cell rupture and disruption of aggregates, as well as dissolved organic matter contamination mainly during filtration by handling, increasing the quantity and changing the quality of the nutrients and organic carbon in the filtrate (Gasol \& Morán 1999, Sherr et al. 1999, Massana et al. 2001). However, even if nutrients or organic carbon concentration remain similar in the filtrate to in situ, substrates can be more available for bacteria when competition is prevented or reduced. Phytoplankton compete with bacteria for nutrients, especially in oligotrophic systems (Litchman et al. 2004); thus, the exclusion of phytoplankton may favour bacterial growth.

Furthermore, filtration procedures and manipulation may cause changes in bacterial community composition. Some studies have shown that long-term incubation after filtration favours the growth of bacteria with a high DNA content (Gasol \& Morán 1999, Massana et al. 2001) and the occurrence of bacterial genotypes with high growth potential in the filtrate (Sherr et al. 1999).

All of these potential pre-filtration consequences are expected to have a major impact in oligotrophic systems (Gasol \& Morán 1999) where the different components of the food web are similar in size and growth rates, and thus both autotrophic-heterotrophic processes and predator-prey dynamics are tightly coupled (Azam et al. 1983, Cotner \& Biddanda 2002).

In our study, the very high mean $\%$ BR measured (154\%) with standard oxygen consumption incubations under oligotrophic conditions suggests a major overestimation of BR after prefiltration. Moreover, the distribution of data frequencies (Fig. 3) indicates that this increase is unpredictable from the data set collected in this study. Nevertheless, both the extent of pre-filtration consequences and the potential exacerbation of such effects by long-term incubations remain to be experimentally demonstrated over different trophic conditions in order to quantify the measurement deviation attributable to each methodological procedure.

\section{Bacterial respiration contribution to community respiration in contrasting trophic conditions}

During the present study, using standard procedures, the \%BR was higher than $100 \%$ (i.e. BR exceeds CR) in $57 \%$ and $3 \%$ of the cases in the oligotrophic and mesotrophic conditions, respectively. Previous investigations have found BR contributions higher than $80 \%$, and even higher than $100 \%$, in oligotrophic situations. For example, Sherry et al. (1999) found that $15 \%$ of the BR data measured in the NE Pacific were higher than the corresponding $C R$, while Biddanda et al. (2001) found that \%BR approximated $100 \%$ in most of the oligotrophic lakes studied. González et al. (2003) found \%BR ranging from 79 to $100 \%$ in the Bay of Biscay when chlorophyll concentrations were $<0.5 \mathrm{mg} \mathrm{m}^{-3}$, and Kirchman et al. (2009) found \%BR exceeding $100 \%$ in the basin region of the western Arctic Ocean associated with low chlorophyll concentration and primary production levels. In most of the above-cited works, \%BR higher than $100 \%$ was considered incorrect and consequently these data were not used in calculations and conclusions. However, \%BR data between 80 and $100 \%$ are usually accepted (Sherry et al. 1999, Biddanda et al. 2001, González et al. 2003). In our study, the \%BR in oligotrophic conditions derived from the in vivo ETS method tended to be $<80 \%$ (Fig. 3). The mean \%BR from in vivo ETS was $31 \%$ (Table 1), and the mean \%BR in oligotrophic conditions, derived from potential fractionated respiration measurements (in vitro ETS method), was 68\%, never exceeding $80 \%$. These results strongly suggest 


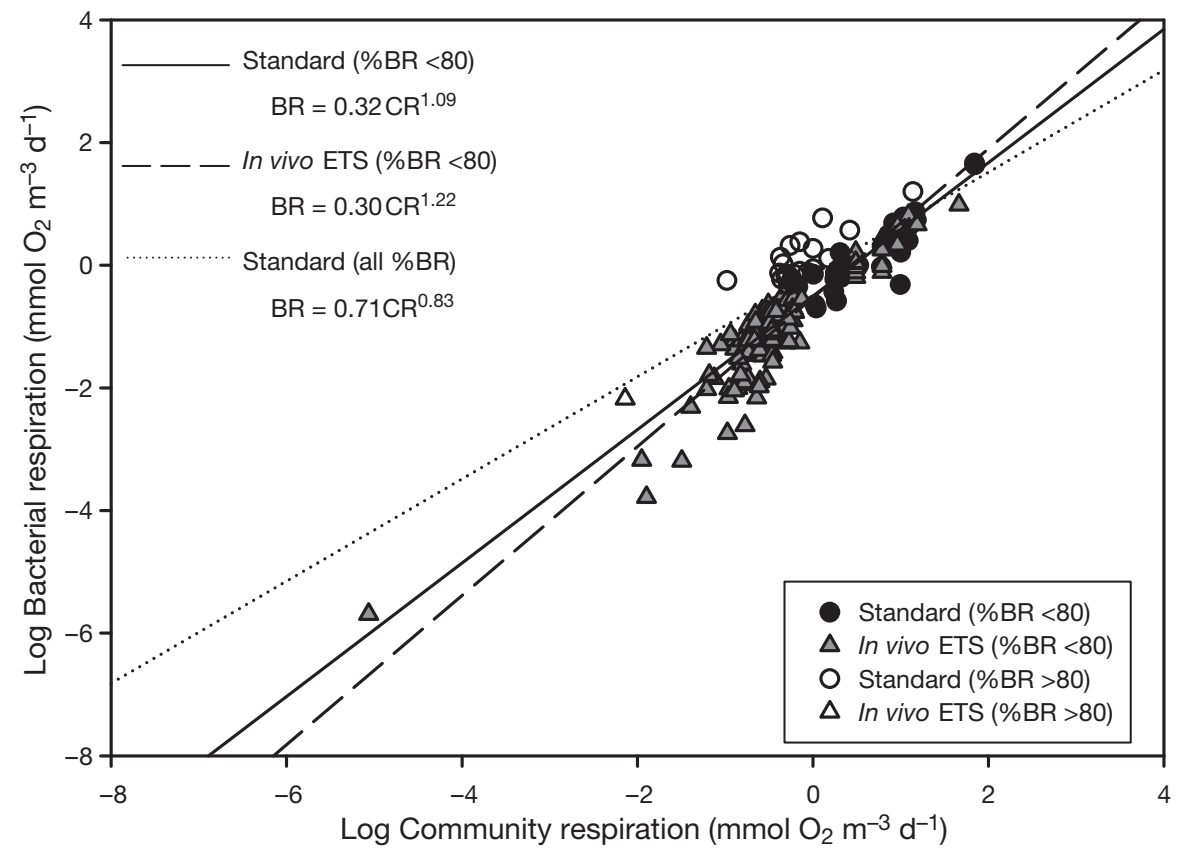

Fig. 4. Type II linear regression between logarithms of community respiration and bacterial respiration $\left(\mathrm{mmol} \mathrm{O}_{2} \mathrm{~m}^{-3} \mathrm{~d}^{-1}\right)$. Circles correspond to the standard procedures and triangles correspond to the in vivo electron transport system (ETS) method. Open symbols correspond to data considered unrealistic (see 'Results and discussion'). Solid and dashed lines represent the type II regression line for standard procedures $\left(\mathrm{n}=42 ; \mathrm{r}^{2}=0.84\right.$; $\mathrm{p}<0.001)$ and the in vivo ETS method $\left(\mathrm{n}=145 ; \mathrm{r}^{2}=0.85 ; \mathrm{p}<\right.$ $0.001)$ realistic data sets, respectively, and the dotted line represents the type II regression line for the complete standard procedures data set $\left(n=63 ; r^{2}=0.61 ; p<0.001\right)$. The corresponding power functions are shown that \%BR values higher than $80 \%$ are unrealistic and are likely derived from methodological artefacts.

The relationship between $\mathrm{CR}$ and $\mathrm{BR}$ shows the fraction of CR attributable to bacteria along the respiration gradient that corresponds to the productivity gradient described before. Fig. 4 presents such a relationship, including all of the available data derived from the different methodologies, excluding those data corresponding to \%BR higher than $80 \%$, considered here as unrealistic (see above). The CR-BR relation for the complete data set of the in vivo ETS samples is not shown in Fig. 4, as it was not significantly different from the relation derived excluding the single $\% B R$ value of $>80 \%$. The exponents of the power functions shown in Fig. 4 are close to 1, so factors multiplying $\mathrm{CR}$ represent the $\mathrm{BR}$ to $\mathrm{CR}$ contribution and can be approximated to the averaged \%BR. When all data are used for the $\mathrm{CR}-\mathrm{BR}$ relation with the standard procedures, the derived \%BR largely exceeds that derived from the non in vivo ETS data (71\% versus $30 \%)$. When data corresponding to \%BR higher than $80 \%$ are removed, both BR methods yield similar \%BR estimates (30 to $32 \%$ ). The similar CR-BR relationship found with both methods when removing unrealistic data allowed us to derive a unique regression equation relating $\mathrm{BR}$ and $\mathrm{CR}$ along the productivity gradient. This regression fit $\left(\mathrm{BR}=0.29 \mathrm{CR}^{1.21} ; \mathrm{n}=187\right.$; $\left.\mathrm{r}^{2}=0.874 ; \mathrm{p}<0.001\right)$ suggests that \%BR approximates $29 \%$ and tends to slightly increase as CR increases.
A similar analysis of the CR-BR relation was made by Robinson (2008) and resulted in a BR contribution of $45 \%$, although $20 \%$ of the data used corresponded to $\%$ BR higher than $80 \%$. The data sets of Robinson (2008) are available in a public database (currently at www.uea.ac.uk/env/people/facstaff/robinsonc), so we were able to reanalyse the $\mathrm{CR}-\mathrm{BR}$ relation by removing the data considered unrealistic (> $80 \%$ ). The resulting new regression equation provides a \%BR of $30 \%$, which is similar to our estimate.

A mean $\%$ BR of around 30\% is substantially lower than the 70 to $90 \%$ value usually accepted for oligotrophic systems (Sherry et al. 1999, Biddanda et al. 2001, González et al. 2003, Reinthaler et al. 2006, Alonso-Sáez et al. 2007). Most of the previously published BR estimates involved long dark incubations of pre-filtered water samples that are potentially subjected to the methodological artefacts described above, as a result of food web link disruption. However, using indirect estimates of BR, many authors have predicted BR contributions similar to ours. Morán et al. (2007) found 33\% BR contribution to CR calculated from bacterial growth efficiency models and measured BP, while Nagata (2000) and Fasham et al. (1999) predicted BR contributions of $35 \%$ and $38 \%$, respectively, with different models of carbon flow through the plankton community. Robinson \& Williams (2005) found an averaged value of $32 \%$ bacterial contribution to CR calculated from biomass determinations across diverse marine systems. In addition, our results agree with recent studies suggesting 
that bacteria do not dominate living-carbon stocks in oligotrophic oceans (Li \& Harrison 2001, Morán et al. 2004), in contrast to the previously reported overwhelming dominance of heterotrophic bacteria in oligotrophic waters (del Giorgio et al. 1997, Biddanda et al. 2001). In fact, our estimation of \%BR in oligotrophic waters can be reconciled with a recently estimated planktonic carbon budget in the eastern subtropical North Atlantic (Marañón et al. 2007) which shows a $20 \%$ contribution of BR to CR.

In conclusion, standard procedures based on prefiltration and long incubations may overestimate BR, particularly in oligotrophic systems characterized by tightly coupled microbial communities. When the non-prefiltration and short incubation in vivo ETS data are analysed, the \%BR approximates 30\% in both meso- and oligotrophic systems. Data considered unrealistic, i.e. those exceeding $80 \%$ of BR contribution to $\mathrm{CR}$, were mainly derived from standard procedures. When those data are removed, the bacterial contribution to total CR varies less than previously assumed and yields a value close to $30 \%$ throughout different productivity systems.

Acknowledgements. We thank all people involved in the projects CARPOS, AddEx and IMPRESION who helped with the preparation and sampling of the cruises and experiments, and the captain and crew on board RV 'Hespérides' and RV 'Mytilus'. We thank Estación de Ciencias Mariñas de Toralla (ECIMAT) for the technical support during the AddEx experiments. We especially thank V. Pérez, A. Anta, I. Menduiña and E. E. García for help with Winkler measurements, and A. Fernández, M. Huete, J. González, P. Cermeño, A. Calvo-Díaz, I. Lekumberri and E. Aguiar for providing primary production, bacteria and chlorophyll a data, as well as P. Figueiras, X. A. Álvarez-Salgado and B. Arbones for organizing and coordinating the mesocosm experiments. We thank J. Morell and J. Corredor for training in the ETS in vitro method. This research was supported by projects CARPOS (MEC, REN2003-09532-C03-03), AddEx (Xunta de Galicia, grant PGIDIT06PXIB312222PR), IMPRESION (MEC, VEM2003-20021), RAFTING (CTM200761983/MAR), CICYT contract (REN2003- 06633-C03) and a European Community Marie Curie Reintegration Fellowship (MERG-CT-2004-511937). M.A.G. was funded by a FPIMICINN fellowship, E.T. was funded by a Juan de la Cierva and a Ramón y Cajal-MEC contract, and S.M.G. was funded by a FPU MEC fellowship.

\section{LITERATURE CITED}

Alonso-Sáez L, Gasol JM, Arístegui J, Vilas JC, Vaqué D, Duarte CM, Agustí S (2007) Large-scale variability in surface bacterial carbon demand and growth efficiency in the subtropical northeast Atlantic Ocean. Limnol Oceanogr 52:533-546

Aranguren-Gassis M, Serret P, Fernández E, Herrera JL, Domínguez JF, Pérez V, Escanez J (2011) Production and respiration control the marine microbial metabolic balance in the eastern North Atlantic subtropical gyre. Deep-Sea Res I 58:768-775

> Azam F, Fenchel T, Field JG, Gray JS, Meyer-Reil LA, Thingstad $F$ (1983) The ecological role of water-column microbes in the sea. Mar Ecol Prog Ser 10:257-263

> Biddanda B, Ogdahl M, Cotner J (2001) Dominance of bacterial metabolism in oligotrophic relative to eutrophic waters. Limnol Oceanogr 46:730-739

> Calvo-Díaz A, Morán XAG (2006) Seasonal dynamics of picoplankton in shelf waters of the southern Bay of Biscay. Aquat Microb Ecol 42:159-174

Cermeño P, Marañón E, Rodríguez J, Fernández E (2005) Large-sized phytoplankton sustain higher carbon-specific photosynthesis than smaller cells in a coastal eutrophic ecosystem. Mar Ecol Prog Ser 297:51-60

> Cotner JB, Biddanda BA (2002) Small players, large role: microbial influence on biogeochemical processes in pelagic aquatic ecosystems. Ecosystems 5:105-121

del Giorgio PA, Cole JJ (1998) Bacterial growth efficiency in natural aquatic systems. Annu Rev Ecol Syst 29:503-541

del Giorgio PA, Cole JJ, Cimbleris A (1997) Respiration rates in bacteria exceed phytoplankton production in unproductive aquatic systems. Nature 385:148-151

> Falkowski PG, Barber RT, Smetacek V (1998) Biogeochemical controls and feedbacks on ocean primary production. Science 281:200-207

> Fasham MJR, Boyd PW, Savidge G (1999) Modeling the relative contributions of autotrophs to carbon flow at a Lagrangian JGOFS station in the Northeast Atlantic: the importance of DOC. Limnol Oceanogr 44:80-94

Fukuda R, Ogawa H, Nagata T, Koike I (1998) Direct determination of carbon and nitrogen contents of natural bacterial assemblages in marine environments. Appl Environ Microbiol 64:3352-3358

Gasol JM, del Giorgio PA (2000) Using flow cytometry for counting natural planktonic bacteria and understanding the structure of planktonic bacterial communities. Sci Mar 64:197-224

> Gasol JM, Morán XAG (1999) Effects of filtration on bacterial activity and picoplankton community structure as assessed by flow cytometry. Aquat Microb Ecol 16:251-264

> Gasol JM, Pinhassi J, Alónso-Sáez L, Ducklow H and others (2008) Towards a better understanding of microbial carbon flux in the sea. Aquat Microb Ecol 53:21-38

> González N, Anadón R, Viesca L (2003) Carbon flux through the microbial community in a temperate sea during summer: role of bacterial metabolism. Aquat Microb Ecol 33:117-126

> Gundersen K, Heldal M, Norland S, Purdie DA, Knap AH (2002) Elemental C, N, and P cell content of individual bacteria collected at the Bermuda Atlantic Time-series Study (BATS) site. Limnol Oceanogr 47:1525-1530

Hansen HP (1999) Determination of oxygen. In: Grasshoff K, Kremling $K$, Ehrhardt $M$ (eds) Methods of seawater analysis. Wiley-VCH, Weinheim, p 75-90

$>$ Jahnke RA, Craven DB (1995) Quantifying the role of heterotrophic bacteria in the carbon cycle: a need for respiration rate measurements. Limnol Oceanogr 40:436-441

> Kirchman DL, Hill V, Cottrell MT, Gradinger R, Malmstrom RR, Parker A (2009) Standing stocks, production, and respiration of phytoplankton and heterotrophic bacteria in the western Arctic Ocean. Deep-Sea Res II 56: 1237-1248

Laws EA (1991) Photosynthetic quotients, new production 
and net community production in the open ocean. DeepSea Res 38:143-167

Legendre L, Rassoulzadegan F (1995) Plankton and nutrient dynamics in marine waters. Ophelia 41:153-172

Li WKW, Harrison WG (2001) Chlorophyll, bacteria and picophytoplankton in ecological provinces of the North Atlantic. Deep-Sea Res II 48:2271-2293

Litchman E, Klausmeier CA, Bossard P (2004) Phytoplankton nutrient competition under dynamic light regimes. Limnol Oceanogr 49:1457-1462

Marañón E, Pérez V, Fernández E, Anadón R and others (2007) Planktonic carbon budget in the eastern subtropical North Atlantic. Aquat Microb Ecol 48:261-275

- Martínez-García S, Fernández E, Aranguren-Gassis M, Teira E (2009) In vivo electron transport system activity: a method to estimate respiration in natural marine microbial planktonic communities. Limnol Oceanogr Methods 7:459-469

- Martínez-García S, Fernández E, Álvarez-Salgado XA, González J and others (2010) Differential responses of phytoplankton and heterotrophic bacteria to organic and inorganic nutrient additions in coastal waters off the NW Iberian Peninsula. Mar Ecol Prog Ser 416:17-33

Massana R, Pedrós-Alió C, Casamayor EO, Gasol JM (2001) Changes in marine bacterioplankton phylogenetic composition during incubations designed to measure biogeochemically significant parameters. Limnol Oceanogr 46:1181-1188

Menden-Deuer S, Lessard EJ (2000) Carbon to volume relationships for dinoflagellates, diatoms, and other protist plankton. Limnol Oceanogr 45:569-579

Morán XAG, Fernández E, Pérez V (2004) Size-fractionated primary production, bacterial production and net community production in subtropical and tropical domains of the oligotrophic NE Atlantic in autumn. Mar Ecol Prog Ser 274:17-29

Morán XAG, Pérez V, Fernández E (2007) Mismatch between community respiration and the contribution of heterotrophic bacteria in the NE Atlantic open ocean: What causes high respiration in oligotrophic waters? J Mar Res 65:545-560

Nagata T (2000) Production mechanisms of dissolved organic matter. In: Kirchman DL (ed) Microbial ecology of the oceans, 1st edn. Wiley-Liss, New York, NY, p 121-152

Norland S (1993) The relationship between biomass and volume of bacteria. In: Kemp PF, Sherr BF, Sherr EB, Cole JJ (eds) Handboook of methods in aquatic microbial ecology. Lewis Publishers, Boca Raton, FL, p 303-307

Olenina I, Hajdu S, Edler L, Andersson A and others (2006) Biovolumes and size-classes of phytoplankton in the Baltic Sea. HELCOM Baltic Sea Environment Proceedings 106. Helsinki Commission, Baltic Marine Environment Protection, Helsinki

Oudot C, Gerard R, Morin P, Gningue I (1988) Precise shipboard determination of dissolved oxygen (Winkler procedure) for productivity studies with a commercial sys-

Editorial responsibility: Matthias Seaman,

Oldendorf/Luhe, Germany tem. Limnol Oceanogr 33:146-150

Packard TT (1971) The measurement of respiratory electron-transport activity in marine phytoplankton. J Mar Syst 29:235-244

Packard TT, Williams PJleB (1981) Rates of respiratory oxygen consumption and electron transport in surface seawater from the Northwest Atlantic. Oceanol Acta 4:351-358

Reinthaler T, Bakker K, Manuels R, Ooijen JV, Hernd GJ (2006) Fully automated spectrophotometric approach to determine oxygen concentrations in seawater via continuous-flow analysis. Limnol Oceanogr Methods 4:358-366

Robinson C, Williams PJleB (2005) Respiration and its measurement in surface marine waters. In: del Giorgio PA, Williams PJleB (eds) Respiration in aquatic ecosystems. Oxford University Press, New York, NY, p 147-180

Robinson C (2008) Heterotrophic bacterial respiration. In: Kirchman DL (ed) Microbial ecology of the oceans, 2nd edn. John Wiley \& Sons, Inc., Hoboken, NJ, p 299-334

Robinson C, Poulton AJ, Holligan PM, Baker AR and others (2006) The Atlantic Meridional Transect (AMT) Programme: a contextual view 1995-2005. Deep-Sea Res II 53:1485-1515

Serret P, Fernández E, Sostres JA, Anadón R (1999) Seasonal compensation of microbial production in a temperate sea. Mar Ecol Prog Ser 187:43-57

Sherr EB, Sherr BF, Sigmon CT (1999) Activity of marine bacteria under incubated and in situ conditions. Aquat Microb Ecol 20:213-223

Sherry ND, Boyd PW, Sugimoto K, Harrison PJ (1999) Seasonal and spatial patterns of heterotrophic bacterial production, respiration, and biomass in the subarctic NE Pacific. Deep-Sea Res II 46:2557-2578

Teira E, Lekunberri I, Gasol JM, Nieto-Cid M, Álvarez-Salgado XA, Figueiras FG (2007) Dynamics of the hydrocarbon-degrading Cycloclasticus bacteria during mesocosm-simulated oil spills. Environ Microbiol 9:2551-2562

> Teira E, Martínez-García S, Fernández E, Calvo-Díaz A, Morán XAG (2010) Lagrangian study of microbial plankton respiration in the subtropical North Atlantic Ocean: bacterial contribution and short-term temporal variability. Aquat Microb Ecol 61:31-43

> Weisse T, Scheffel-Möser U (1991) Uncoupling the microbial loop: growth and grazing loss rates of bacteria and heterotrophic nanoflagellates in the North Atlantic. Mar Ecol Prog Ser 71:195-205

> Welschmeyer NA (1994) Fluorometric analysis of chlorophyll $a$ in the presence of chlorophyll $b$ and pheopigments. Limnol Oceanogr 39:1985-1992

> Worden AZ, Nolan JK, Palenik B (2004) Assessing the dynamics and ecology of marine picophytoplankton: the importance of the eukaryotic component. Limnol Oceanogr 49:168-179

Zubkov MV, Sleigh MA, Tarran GA, Burkill PH, Leakey RJG (1998) Picoplanktonic community structure on an Atlantic transect from $50^{\circ} \mathrm{N}$ to $50^{\circ} \mathrm{S}$. Deep-Sea Res I 45:1339-1355

Submitted: August 4, 2011; Accepted: March 5, 2012

Proofs received from author(s): April 23, 2012 